\title{
Robbery, Blood Feud, and Gunpowder in Nestorian Community
}

\author{
Assist. Prof. Dr. Murat Gökhan Dalyan \\ Faculty of Education, Adiyaman University, 02040 Adiyaman, Turkey \\ E-mail:mgdalyan@adiyaman.edu.tr
}

Received: March 10, $2011 \quad$ Accepted: April 10, $2011 \quad$ doi:10.5539/ass.v7n8p81

\begin{abstract}
The Nestorians acquired combative character due to features of region where they lived and struggle with their Kurdish neighbours. Inaccessibility of the valleys they lived in reinforced their self-confidence and in consequence of that they robbed all the foreign people especially Kurds and Catholic missionaries who intruded into their territory without permission.

The Nestorians were interested in weapons and adult men had a curved dagger that was thought to be a national weapon. Among the Nestorian tribes, blood feuds occasionally took place due to various reasons and killings occurred. Tribes in the blood feud did not hesitate to make alliance with their Kurdish neighbour in order to defeat the each other.
\end{abstract}

Keywords: Nestorian, Robbery, Blood feud, Gun, Women

\section{The Concept of the Nestorian}

Nestorians are Christian society who lived nomadic and sedentary lifestyle in Hakkari and Urmia regions of territory of the Ottoman State and Iran in the $19^{\text {th }}$ century. The nomadic Nestorian people lived in Hakkari region of the Ottoman State while sedentary ones generally lived with their Muslim neighbour together on the fertile agricultural lands of Northwest of Iran, rural areas of Van-Hakkari, Amediye, and Bedirhan regions which were East and Southeast region of the Ottoman State (Dalyan 2009).

\section{Combative Character of the Nestorians}

The nomadic Nestorian tribes living on the mountains of Hakkari gained a combative character because of the condition of life and struggle with their Kurdish neighbour (Maclean and Browne 1891; Perkins 1843; Fraser 1842; Coleman 1858; Dwight 1840). Another prominent reason forcing them to be offensive and wild against the external threats was that structure of the land which they lived on gave opportunity to form a natural defence against enemies (Report Of The American Board: 1837). Therefore, even though they were few compared with Kurds, they became quite successful in fighting (Perkins 1843; Wigram 1991). On account of this character of Nestorians, foreigners and Kurds were careful to enter into the harsh and impassable valley where Nestorians were. If a foreigner set foot in the Nestorian territories without permission, he would be thrown to the Great Zab after killing. In this context, Nestorian tribes fought with not only foreigners but also each other (Perkins 1843; Termen 1910). Eliya Vartanov stated “... They were jealous of each other... they committed burglary, took the sheep of their neighbours to their herd and fought with each other."(Vartanov 2005, p. 31) Even, owing to their self-confidence resulting from mountainous area and tough personalities, they attacked to the soldiers and officers of Ottoman State who passed through the Nestorian's territory ( YMTV 35/146).

At the beginning of $19^{\text {th }}$ century, Nestorians had castles leaning against rocky places except for sheltering valleys in order that they could defend themselves against enemies. The only known sample of such kind of castles that was devastated by Kurdish invasions in the $19^{\text {th }}$ century was the castle in the village Zeir which was had existed in ruins until 1856 (Marsh 1865). In some Nestorian villages, watchtowers were established for preventing the Kurds from looting and plundering (Ainsworth 1842). During 1830s, the Nestorian patriarch could raise 12.000 armed forces in an emergent situation (Fraser 1842). In another record, the number of armed forces the patriarch could raise is 15.000 (Sehil 1856).

\section{Gun and Nestorians' Affection for Gun}

Nestorian always carried weapons such as musket and dagger owing to harshness of the region and struggle with Kurdish neighbours (YPRKDH 9/26; Perkins 1843). The life conditions resulted in that children of nomadic tribes received military training mostly. According to this approach, every boy who had turned 9 or 10 were 
given bow and arrow by their family and when boys grew a little more, a curved dagger that could be appropriately hidden in their dresses was given them (Lalayan 1914). Therefore, Every Nestorian adult man who bore arms in the mountain of Hakkari was accepted as soldier (Perkins 1843; Coleman 1858). Like civilians, Nestorian monks used weapon and cutting tools such as dagger (Heazal 1913; Cutts 1877; Ainsworth 1842). Nestorians having fondness of poniards and firearms (Ainsworth 1842) were seen as belligerent (Millingen 1998) and wild people who had ability to use guns well (Ainsworth 1842). Due to the affection for gun and struggle, all young men took weapons, went church to pray, and they showed their shooting ability outside after the religious ceremony. Those who had horse showed their ability to the people who do not know how to rear horse (Lalayan 1914). Among the Nestorian tribes, especially Tiyari and Tal were outstanding tribes in terms of combativity (YPRK 48/69; Campbell 1844; Rich: MDCCCXXXVI). The Tiyari tribe could raise an armed force which made up of approximately 5 or 6 thousand soldiers in 1895. Besides, this tribe succeeded in fighting off three regular battalions which were sent to subdue the Nestorians who attacked Muslim villages in 1890 (YPRK. DH. 9/26). Throughout $19^{\text {th }}$ century, Nestorian fighters usually bore flintlock gun and ammunition belt belonging to this gun, shot bags, poniard and daggers (Coan 1939:144). Among these weapons, curved daggers were national ones which Nestorian males could not manage without (Cutts 1877). One of the biggest aspirations of every Nestorian living in mountainous was to have better and more modern weapon (Coan 1939). During 1890s, the government of Iran gave modern weapons and ammunition to the Nestorians living on borderland of Ottoman-Iran such as the Village Mevana in order that they could defence themselves against Kurdish plunderers. As a result, some of the Nestorians obtained modern weapons (Mildred, 1894; Heazal, 1913). Until recently, both sides, Nestorians and Kurds, had fought with each other by using the same weapons and ammunition (Perkins, 1843).

\section{Robbery}

Nestorians living in the mountains were notorious for robbery as well as their combativity. At the end of an ambush in the prominent passes they caught the travellers in their region and interrogated them in accordance with their expressions and appearances. The people which they robbed were usually the Kurds robbing Nestorians and Catholic people in sectarian conflict with them. The Protestant missionaries travelling in the Nestorian regions despite not being Catholic could not escape in facing bad events.(Grant, 1994; Marsh, 1865) Since Nestorians noticed that missionaries entering in their territory without permission had money to bring them into the fold, they did not hesitate to rob the missionaries(FNH, 1899). Therefore, English traveller Ainsworth (1842) stated that travellers in the Nestorian region could not protect their property against robbers (Ainsworth, 1842). In 1889, Meliki Berku and his men of Gawia region robbed a French monk travelling in the Hakkari Mountains. On account of this robbery, missionaries of ABCFM Frederick G. Coan that was involved in missionary activity in Thuma of Hakkari Mountains had to stay in the village Muzira for one night. In spite of all the precautions taken for night, robbers stole his clothes and properties. Yet, Coan's properties were found thanks to the attempts of Khoja Suleiman/Hoca Suleyman who lived and received education abroad. After a while, Melik Babo/Baboo of Thuma Meliks supposed three crates containing medicine carried by Coan were full of gold and Melik Baboo waited for robbing him in the valley he would pass as though he had been waiting for taking his stolen sheep for two days. Khoja Suleyman warned Melik Baboo through his men owing to the fact that earlier theft incident hurt his pride and Khoja Suleyman dissuaded him from this burglary attempt. Later, Coan met with head to toe armed Melik Baboo and asked him why he wanted to rob himself. Melik Baboo said that he did not intend to rob him and this was a false claim of his enemies. Coan did not believe him and threatened by saying that if any harm came to him, the Nestorian image in the West would be damaged and allies would wipe Thuma off the map. Nevertheless, missionary Coan was harassed by Melik Baboo and his men and unpleasantness took place.

As cases above, travelling in Nestorians of Hakkari Mountains was sometimes frightening to the missionaries of ABCFM. Nestorians robbed not only missionaries coming from abroad but also some of the missionaries who were permitted in Nestorian region. English missionaries Browne was robbed by cousin of Mar Samun who had enmity to him and thrown from a high place after tying his hands and legs with rope. However, Browne did not die (Heazal, 1913; Termen, 1910).

Later, except for missionaries and Kurds, the other foreigners were robbed in the Nestorian region. During a travel in Hakkari Mountains, Russian vice consul Termen says "when I wanted to go these mountains, English missionaries warned me. The reason was the likelihood of facing many difficulties. Indeed, I was restrained by the people of village Tiyari. My aide was injured, his musket was taken and I was about to be robbed. Nevertheless, when they learnt that I was the Russian vice consul, but not a missionary, they insistently claimed my aide swore at them. After changing mind, they gave back the musket and I was allowed to leave there proudly. So, those who want to travel among the Nestorians living in Hakkari Mountains had to show the 
document for travel given by Nestorian patriarch in Kocanis during passing through these regions. Otherwise, there could not be a safe travel. In these regions, even the document of permission was sometimes invalid to Nestorians.

There were people who took the necessary letter from the patriarch in order to travel in a safe way and a number of oral rules that foreigners had to obey except for this letter. This kind of gifts ensured that foreigners could travel comfortably and acquire his trust (Maclean and Browne, 1891). Foreigners who did not have this kind of letters and assurances were considered enemy and killed, and later their bodies were thrown into the river (Perkins 1843). English military officer Co Bell appointed in India, American missionary Coan, and French Catholic missionary faced Nestorians' such kind of treatments and their clothes and property were stolen (The Fifty- First Annual Report Board, 1888). Mainly due to the fact that missionaries lived with Nestorians and foreigners often visited their territory despite robberies, Nestorians occasionally attempted looting and rampage on the caravan route of Mosul and Hakkari at the end of XIX century (Y.E.E 132/26).

Also, Nestorians' combative character and ferocity led a number of false beliefs circulating from person to person in the Muslim community around Nestorians. Therefore, they were not allowed to stay in Amediye at night since they were the people who exterminate humans by using variety of magic words. This kind of superstition spreading throughout the region caused people to be frightened of them. The brutality of Nestorians played a remarkable role in the increase of these superstitions. For example, at the end of a clash with Kurds of Ravanduz who stole the Nestorians' herds, 6-7 Kurds were decapitated and their head were hung from the bridge going to Nestorian region. This kind of incidents led Nestorians to have a terrible reputation among the Muslims. Mosul's Pasha Muhammed said American missionary Grant that Hakkari Mountains had not been safe to travel and warned Grant of life safety (Campbell, 1844; Grant, 1994). Yet, there was no constant hostility between Nestorians and Muslims, but, this does not mean that they did not have hostile attitude to each other (Ainsworth, 1842).

Combativity was not just the peculiar to the Nestorian civil people. Also, religious men could use weapons well. In 1840, English missionary Ainsworth (1842) says that a Nestorian bishop wearing sword, dagger, and armour waited for themselves while entering into a Nestorian village. As a result of all these peculiarity of Nestorians, missionaries mention the high prevalence of looting and robbery among the Nestorian in mountain (Heazal, 1913; Coan, 1939). Robbery and looting were perceived as normal, such kinds of acts were usually against Kurds and foreigners, and if any property was acquired, people around the region would be told proudly (Wigram, 1991).

In 1912, Christians of Salebakan stole 500 sheep of Kurds of Cal through attacks in the middle of the night. However when, on the way back, they noticed that stealing the sheep without the aware of enemies had no satisfying act, they came to the near of the village of Kurds of Cal. Christians of Salebakan awakened the Kurds with acts like firing gun and clashed with them. At the end of the incident, they killed three people, including one Ottoman police man. The Nestorians obtained the 500 sheep as well as four guns (Wigram, 1991).

In the 19th century, of Nestorians, Tiyari tribe and tribes in the valley of Diz were skilful in robbery. Tiyari tribe gave the $10 \%$ of herd and property which they got after robbery and looting to the Meryemana (Mart Miriam) Church in the valley of Walto. English missionary Wigram says that if the priests were clever, they sometimes took seventh of the commodity brought by robbers and plunderers. This was because the priests had important roles in making plundering and looting against Muslims religiously lawful. For example, Nestorians of Diz who stole a cow from Muslims had a dispute about whether the cow was legal or not. The priest of region of Diz consulted about this matter blessed the cow by praying and made it cuttable (Wigram, 1991).

\section{Blood Feuds in the Nestorians}

The Blood feuds in Nestorians were because of several reasons such as pasture and theft of sheep and it was long lasting. As it was too difficult to end the blood feud, many people died and got injured. Although even the Nestorian patriarch occasionally engaged in resolving this kind of matters, he was not capable of ending feuds peacefully at times (Coan, 1939). Yet, if the blood feud between tribes resulted from a simple reason, parties would end this matter by paying a certain amount of blood money through mediaries (Cutts, 1887).

When the blood feuds in Nestorian tribes was violently intensified, parties made no bones about calling help of Kurds and establishing alliance with them(Maclean and Browne, 1891). In 1888, the Diz tribe, one of the Nestorian tribes of Hakkari region, established an alliance with their neighbours the Bilicani tribe so as to cope with the Tiyari tribe which had conflict with the Diz tribe. The Tiyari tribe retaliated for this alliance by allying with their neighbours' tribe Ertusi. The Ottoman State sent troops to the region in order to prevent the tension between the Nestorian troops from turning into a conflict (YPRK 14/15). After a year, a blood feud broke out between Baz and Cilolu tribes, this incident was intensified and it caused the death of many people in both two 
parties. After the engagement of bishops in the blood feud, the two parties were reconciled and this feud ended. However, in Nestorians, blood feuds occasionally took place owing to various kinds of reasons even at the beginning of $20^{\text {th }}$ century (Cutts, 1887).

\section{Gunpowder and Manufacture of Ammunition}

A part of mines in the Ottoman State was located in the Hakkari region where Nestorians lived. Minerals were scattered in the different settlement and iron rose to the surface in the mountain close to Nestorian village Dure around Amediye, lead and copper in oxidized condition (Grant, 1994; Surma and Samcun, 1996; Campbell, 1844) were located around Marguza in the Tiyari region (Surma and Samcun 1996, 57). Except for these minerals, it is known that zarnich mining was located in Hakkari and around it and this mining changed hands continuously during the Ottoman-Persian wars in $19^{\text {th }}$ century (C. DH 14/66)

Nestorians obtained necessary bullets for their muskets from the copper deposit on the outskirts of mountains around the Village Sumba situated on the Great Zab. The lead extracted from the mineral veins on the surface of the land was ready to use after warming the lead and pouring it into a thimble. By doing so, Nestorians manufactured their ammunition without needing any foreign assistance (Coan, 1939; Matiyef, 1996).

They manufactured the necessary gunpowder by mixing the sulfur, which was abundant on the hills close to the settlements, and ash of walnut or oak tree. In addition, they obtained the saltpetre which is an important substance used in making gunpowder, from the fertilizers in the caves used for shelter of the sheep (Hülagü, 2001) because it was known that feces of animal contains large quantity of nitrogen, basic substance of saltpetre.

After the suggestion of English missionary Wigram, recently, Nestorians began to use the wood of willow rather than that of oak and walnut since the wood of willow is more suitable for the manufacture of the gunpowder. During the ends of the 19th century, an ingenious priest of Nestorians succeeded to convert the breech-loading musket to the Martini-Henry rifle that was the most favoured weapon of the time and he made too much money (Wigram, 1991). It is understandable that Nestorians could meet the needs of weapon and gunpowder without receiving any foreign assistance (Grant, 1994). Therefore, they did not need any foreign assistance in the conflict with themselves and Kurds.

\section{Nestorian Women and War}

The Nestorian women had conversation and meeting with men and they did not hesitate to discuss with them (Layard, 2000). Also, they sometimes assisted men in protection of village, conflict, and war. Matiyef (1996) says "they participated in the units protecting village and they were involved in war as well as." From this statement, it is understood that women's participation in war against Nestorian's neighbours as if they had been warrior had role in the increase of the casualty of women life (Matiyef, 1996, p.21). Yet, according to Wigram, women were not generally killed in the conflicts with Kurds until the end of the empire. Both Nestorians and Kurds regarded women as untouchable beings. During the reign of Abdulhamid II, their power was equal in general. The rule was simple: "take whatever you like, but do not harm the things left behind and do not touch women". This rule was so well-known that protection of women was unnecessary. During the Nestorians' war with Kurds or Kurds' war with themselves, the girls of Christian community under their control as well as the property of loser were sometimes taken. However, even in this situation, the rule that women were untouchable holy beings was valid (Wigram 1991, p.210-211).

In another work of Wigram (1991, p.22), he ascertained that "both Nestorians and Kurds had the tradition of marriage with enslaved women (at the end of the conflict, winner took the women of the loser and got married with them."

\section{The Role of Religious Men in Wars}

Nestorian religious men undertook considerable active roles in military affairs except for religious tasks. For example, the assistance of priests participated in the war between the tribes or war with the neighbours. Wigram informs about the duty of the assistance of the priests by saying "if the condition required, they participated in war. Many respected assistances of priests performed the task of guiding through war as well as worship. Furthermore, according to him, in the wars, they served not only their community but also their ally or Kurdish neighbours having close relation. The second commander of Bedirhan Bey, the head of Kurds of Beyzadi, was an assistant of Nestorian priest. This assistant stated that Bedirhan Bey brought the people in his village and Kurds to the war (Wigram, 1991)

George M. Lamsa attributes the fact that Nestorian priests undertook the leadership of Nestorian community in the wars with their neighbours to a tradition from Luwians, an old people lived in Mesopotamia in antiquity (Emhardt and Lamsa, 1926). English missionaries say that the skill of using gun and dagger of Nestorians' 
religious men in the missionary schools was better than the reading and writing in old Syriac language (Heazal, 1913). In 1840, English missionary Ainsworth says (1842) that a Nestorian bishop wearing sword, dagger, and armour waited for themselves while entering into a Nestorian village.

\section{Conclusion}

The travellers and missionaries described the Nestorian society in the $20^{\text {th }}$ century as combative and gun enthusiast. The reason why they acquired this character is the conflict with Kurds and the fact that the region, where they lived was protected. During the conflicts, all of the men, women, and religious men participated in the struggles. Their bellicose traits led the continuation of blood feud between themselves. Even they did not hesitate to make alliance with their Kurdish neighbours so as to maintain superiority over each other.

In the same century, Nestorians' another character that is as prominent as their combativity was keenness of robbery. The robbery is enjoyable and something needing to be told proudly. Thanks to the mining in their region, they manufactured the bullet and gunpowder used in the robbery and conflicts without any foreign assistance

\section{References}

\section{Books and Articles}

Ainsworth, William Francis. (1842). Travels and Research in Asia Minor, Mesopotamia, Chaldea, and Armenia, Vol. II. London: John W.Parker, West Strand.

American Board of Commissionaries for Foreign Missions. (1837). Report of The American Board of Commissionaries For Foreign Missions, Read At The Twenty-Eight Annual Meeting, Held in The City of Newark, N.J., September 13, $14 \&$ 15, 1837. Printed for the Broad by Crocker and Brewster, Boston, 63-69.

Anderson, Rufus. (1872). History of the Missions of the American Board of Commissionaries Foreign Missions to the Oriental Churches, Vol. I. Boston.

Anderson, Rufus. (1884). History of the Missions of the American Board of Commissionaries Foreign Missions to the Oriental Churches, Vol.II. Boston.

Annual Report Board of Foreign Missions of the Presbyterian Church. (1888). The Fifty- First Annual Report Board of Foreign Missions of The Presbyterian Church of The United States of America Presented To The General Assembly, May. 1888. New York, Mission House, 53 Fifth Avenue, 77-86.

Annual Report Board of Foreign Missions of the Presbyterian Church. (1900). The Sixty-Third Annual Report Board of Foreign Missions of The Presbyterian Church of The United States of America Presented to The General Assembly May. 1900. New York, Mission House, 53 Fifth Avenue, 198-208.

Badger, George Percy. (MDCCCLII). The Nestorians and their Rituals with the Narrative of a Mission to Mesopotamia and Koordistan in 1842-1844 Vol. c. I. London: Joseph Masters.

Bird, Isabella L. (1891). Journey of Persia and Kurdistan including A Summer in the Upper Karun Region and Visit to the Nestorian Rayahs Vol. II. London.

Campbell, William W. (1844). A Memoir of Mrs. Judith S. Grnat, Late Missionary to Persia. New York.

Coleman, Lyman. (1858). Ancient Christianity Exemplified in the Private, Domestic, Social, and Civil Life of Primitive Christians, and in the Original Institutions, Offices, Ordinances, and Rites of the Church. Philadelphia: Lippincott, Grambo \& Co.

Cutts, Edward. (1877). Christians under the Crescent in Asia. London.

Cutts, Edward L. (1887). The Assyrian Christians. Report Of A Journey, Undertaken By Desire Of His Grace The Archbishop Of Canterbury And His Grace The Archbishop Of York, Christians in Koordistan And Oroomiah. London: R. Clay, Sons, And Taylor.

Dalyan, Murat Gökhan. (2009). 19. Yüzyll'da Nasturiler, (İdari-Sosyal-Yapı ve Siyasal İlişkiler) University of, Süleyman Demirel, Institute of Social Sciences. Unpublished Ph. D. Thesis, Isparta.

Dwight, Harrison Gray Otis. (1840). Memoir of Mrs. Elizabeth B. Dwight: Including an Account of the Plague 1837, New-York.

Emhardt, William Chauncey and Lamsa, George M. (1926). The Oldest Christian People A Brief Account of The Assyrian People Abd The Fateful History Of The Nestorian Church. The Macmillan Company, New York. 
F.H.I. (1897). In Persian Kurdistan, Quarterly Report of Assyrian Mission, No. XXVIII. Published for the Assyrian Mission London, 165-173.

F.N.H. (1899). From Mr. Heazell's Diary, Quarterly Report Of Assyrian Mission, No. XXXIX. Published for the ssyrian Mission London, 343-346.

F.N.H. (1900). Tyari, Quarterly Report of Assyrian Mission, No. XL. Published for the Assyrian Mission London, 364-366.

Fraser, J.Baillie. (1842). Mesopotamia and Assyria, From the Earliest Ages to Present Time; With Illusrations of Their Natural History. New York.

G. Coan, Frederick. (1939). Yesterday in Persia and Kurdistan. California: Saunders-Studio Press.

Grant, Asahel. (1841). The Nestorian; or, The Lost Tribes, The Monthly Review, From May to August Inclusive 1841 Vol.II. London.

Grant, Dr. Asahal. (1994). Nasturiler ya da Kayıp Boylar, Trans. Meral Barışand Bet-Prasa-Bet-Froso. Södertalje-Sweden: Nsibin Yayınevi.

Heazal, F. N. Margoliouth. (1913). M.A., Kurds \& Christians. London.

Hülagü, Metin. (2001). Osmanlı Devleti'nde Güherçile Üretimi ve Kayseri Güherçile Fabrikası. University of Erciyes Journal of Institute of Social Sciences, 11, 73-93.

Lady Sehil. (1856). Glimpses Of Life Manners in Persia. London.

Lalayan, E. A. (1914). Van Bölgesinde Asurlar. Trans. Edip İhsan Polat, Tiflis.

Laurie, Thomas. (1853). Dr.Grant and the Mountain Nestorians. Boston.

Layard, Austen Henry. (2000). Ninova ve Kalıntıları Kürdistan'ın Keldani Hiristiyanları, Yezidiler ya da Seytana Tapanların Ülkesine Bir Gezi, Eski Asur'un Töre ve Sanatlarının Araştırılması, Trans. Zafer Avşar, İstanbul: Avesta Basin Yayın.

Maclean, Arthur John and Browne, William Henry. (1891). The Catholicos of the East and His People, Being the Impressions of Five Years Work in the Archbishop of Canterbury's Assyrian Mission" An Account of the Religious and Secular Life and Opinions of the Eastern Assyrian Christians of Kurdistan and Northern Persia (Know also as Nestorians). London.

Mar Samcun, Surma, D. and Byat. (1996). Ninova'nın Yakarlşı Doğu Asur Kilise Gelenekleri ve Patrik Mar Şamun'un Katli, Trans.. Meral Barış, İstanbul:Avesta Yayınları.

Marsh, Dwight W. (1865). The Tennessean in Persia and Koordistan Being Scenes and Incidents in the Life of Samuel Audley Rhea. Philadelphia: Presbyterian Publication Committee.

Matiyef KP. (1996). Asurlar, Modern Çağda Asur Ulusal Sorunu. Trans. Murat Kara, Nsibin Yayınevi.

Mildred, Katharine. (1894). The Sisters' Journey And Work. Quarterly Report Of Assyrian Mission. Published For The Assyrian Mission, London.

Millingen, Major Frederick. (1998). Kürtler Arasında Doğal Yaşam. Trans. Nuray Mestçi, Istanbul: Doz Yayınları.

Perkins, Justin. (1841). The Nestorian Christians. The American Biblical Repository, January 1841, Second Series, No IX-Whole No.XLI. New York.

Perkins, Justin. (1843). A Residence of Eight Years in Persia among the Nestorian Christians. New York: Allen, Morrill \& Wardwell.

Perkins, Justin. (1868). Missionary Life in Persia Being Glimpses of the A Century of Labros Among The Nestorians. Boston.

Rawlinson, George. (1862). The Five Great Monarchies of The Ancient Eastern World; The History, Geography, And Antiquities of Chaldea, Assyria, Babylon, Media, And Persia, Collected And Illustrated From Ancient And Modern Sources Vol.I. London.

Rich, Claudius James. (MDCCCXXXVI). Residence in Koordistan, and on the Site of Ancient Nineveh; with Journal Of Voyage Down The Tigris To Bağdat And On Account Of Visit To Shtrauz And Persepolis, Vol. London. 
Termen, I.R. (1910). 1906’da Van Bölgesindeki Hakkâri Dağlarına Düzenlenen Bir Gezi İle İlgili Rapor, Trans. Edip İhsan Polat, Tiflis.

Tızlak, Fahrettin. (1996). XIX. Yüzyılın Ortalarında Osmanlı Maden Yatakları, Belleten 229 Ankara: TTK Yayınevi.

Vartanov, Eliya (2005). Sibirya Sürgünü Asurîlerin Anıları (1949-1956). Trans.. H. Topuzoğlu, İstanbul: Yaba Yayınlar1.

Wigram W.A. (1991). En Küçük Müttefikimiz, Trans. Yaşar Günenç, Södertâlje-İsveç:Nsibin Yayınlar:10.

\section{The Republic of Turkey- Prime Ministry Ottoman Archive}

C.DH. Dosya No. 14 gömlek No.66.

C.DRB Dosya No.31 Gömlek No.1544.

DH.MKT. Dosya No: 2202 Gömlek No: 44

İ.MSM Dosya No:48 Gömlek No:1229.

Y.E.E. Dosya No: 132 Gömlek No: 26.

Y.MTV. Dosya No: 35 Gömlek No:146.

Y.PRK. BŞK. Dosya No: 14 Gömlek No: 15.

Y.PRK. UM. Dosya No: 48 Gömlek No: 69.

Y.PRK.DH. Dosya No: 9 Gömlek No:26. 